\title{
Swimming performance of the migratory Neotropical fish Leporinus reinhardti (Characiformes: Anostomidae)
}

\author{
Hersília de Andrade e Santos*, Paulo dos Santos Pompeu** \\ and Carlos Barreira Martinez*
}

The fishways built in Latin America were mainly based on those used in the northern hemisphere for passing salmonids upstream. However, the swimming capacity in terms of speed and endurance is a major factor concerning the design of a fishway, and this information is not available for migratory neotropical fish species. Therefore, studies on swimming performance of neotropical species is fundamental. The aim of this study was to estimate the critical, sustained and prolonged speeds for the piau-três-pintas Leporinus reinhardti, and to evaluate the influence of water temperature on the swimming performance of the species. Variable (increasing) and fixed velocity tests were performed in a respirometer. When compared to other species whose critical speed data are available, the piau showed higher speeds, for a given total length. Fatigue times per prolonged speed class were estimated as well as prolonged speed per fatigue time class. The changing point from sustained to prolonged swimming was estimated to occur approximately at a speed of seven body-lengths per second $(1.12 \mathrm{~m} / \mathrm{s}$ for an individual with $16 \mathrm{~cm}$ total length: the first maturation length). In spite of the great swimming performance of piau, the adoption of efficient directives in fishway projects to allow the passage of neotropical ichthyofauna, will depend on a more detailed analysis of the swimming capacity of different species.

As passagens para peixes construídas na América Latina são principalmente baseadas nos dispositivos existentes no hemisfério norte que, por sua vez, foram dimensionados para salmonídeos. Entretanto, a capacidade natatória das espécies migradoras, em termos de resistência e velocidade, é o principal fator a ser considerado no dimensionamento de uma passagem para peixes e estas informações ainda não são conhecidas para as espécies migradoras neotropicais. Dessa forma, o estudo da capacidade natatória das espécies neotropicais tornou-se uma necessidade. Este estudo tem como objetivo estimar as velocidades crítica, sustentável e prolongada do piau-três-pintas, Leporinus reinhardti, bem como avaliar a influência da temperatura da água na capacidade natatória. Testes de velocidade variável e fixa foram desenvolvidos em um aparato experimental do tipo respirômetro. Quando comparado a outras espécies, cujos dados de velocidade crítica são disponíveis, observa-se que o piau apresenta velocidades superiores para um mesmo comprimento total. Tempo de fadiga por classe de velocidade prolongada foram obtidos bem como a velocidade prolongada por classes de tempo de fadiga. O ponto de mudança do modo sustentável para o modo prolongado de natação foi estimado ocorrer em, aproximadamente, sete comprimentos por segundo (1.12 m/s para indivíduos com $16 \mathrm{~cm}$ de comprimento total: comprimento de primeira maturação). Apesar da grande capacidade natatória do piau, a adoção de critérios eficientes para o projeto de mecanismos de transposição para peixes neotropicais dependerá de análise detalhada da capacidade natatória de diferentes espécies.

Key words: Prolonged speed, Critical speed, Sustained speed, Fishway.

\section{Introduction}

The blockage of rivers causes intense modifications in aquatic environments and related communities (Sale, 1985). Dams built for the purpose of hydroelectric power are the main reason for such impacts. The new environment formed presents distinct characteristics compared to the original river, and communities undergo significant changes. An unavoid- able result is the alteration in abundance and richness of species, with proliferation of some and reduction of others or even elimination of certain species (Agostinho, 1994). Among the aquatic communities, the impacts on fish should be carefully considered because they are easily observed in the environment and they have economic value (fisheries), in addition to their vulnerability to changes in other components of the aquatic system.

\footnotetext{
*Centro Federal de Educação Tecnológica de Minas Gerais, Campus II, Av. Amazonas, 7675, Nova Gameleira, 305000-000 Belo Horizonte. MG. Brazil. hersilias@yahoo.com.br

**Universidade Federal de Lavras, Departamento de Biologia, Ecologia. 37200-000 Lavras, MG, Brazil.
} 
Dams represent obstacles to fish species that need to migrate to complete their life cycle, altering recruitment in their populations. However, only a fraction of neotropical species is in fact migratory (Petrere Jr., 1985; Godinho \& Godinho, 1994), but they are the most important for professional (Goulding, 1979; Bittencourt \& Cox-Fernandes, 1990; Godinho, 1993) and sport fisheries in South America, due to their larger sizes and abundance (Northcote, 1978).

Many alternatives considered to minimize the adverse effects of barriers on fish migration have been proposed and implemented, such as the construction of fishways. These are basically water conduits (open or closed), where the hydraulic energy is dissipated by internal obstacles, to facilitate fish moving through it without excessive stress. The first fishways built in Latin America followed the design used in the northern hemisphere for passing salmonids upstream (Quirós, 1989). However, neotropical fish are different from those found in the northern hemisphere (Clay, 1995), considering migratory strategies and the swimming behavior. Since the swimming capacity in terms of speed and endurance is a major factor concerning the design of a fishway (Beach, 1984), it is possible to determine whether it has a negative influence on the efficiency of the fishways already built in South America. Consequently, studies of the swimming performance of the main neotropical species are mandatory for the improvement of neotropical fish passage design, and this represents a great challenge, because South America species richness encompasses approximately 4,500 fish species (Reis et al., 2003).

Usually, fish swimming can be divided into three categories: sustained, burst and prolonged speeds (Beamish, 1978). Sustained swimming contains a spectrum of swimming speeds that can be maintained for an indefinite period of time, longer than $200 \mathrm{~min}$, and fatigue is not involved. Burst swimming involves rapid movements of short duration, less than 15-20 min, and high speeds. This kind of swimming uses anaerobic processes. Prolonged swimming covers a spectrum of speeds between burst and sustained and have more often been measured in the laboratory. The main subcategory is the critical speed, which was first defined and employed by Brett (1964). Critical swimming speed is a common measure of the relationship between exercise intensity and duration within the prolonged performance envelope (Peake, 2004).

In Latin America, fish communities in large rivers comprise mainly siluroids and characins (Quirós, 1989). Piaus (Anostomidae) are some of the main representatives of the order Characiformes. Their distribution is wide on the continent, inhabiting large river basins (main channel and tributaries), including the Magdalena and Atrato rivers in Colombia, Orinoco River and the Maracaibo lake system in Venezuela and the drainage systems of Brazil, from Amazon to the south of Buenos Aires in Argentina. Some members of the genera Leporinus perform spawning migrations in the Paraná-Paraguay system (Godoy, 1967), São Francisco River basin (Sato et al., 1987), and in the Amazon and Orinoco basins (Goulding, 1979). These migratory species are exploited in commercial and subsistence fisheries as an important food item for people (Goulding, 1979; Bittencourt \& Cox-Fernandes, 1990; Godinho, 1993). The piau-três-pintas (Leporinus reinhardti) is a middlesized migratory species, abundant along the entire São Francisco River basin, including tributaries (Alves \& Pompeu, 2005). Therefore, aim of this study was to estimate the critical, sustained and prolonged speeds for the piau-três-pintas $L$. reinhardti, and to evaluate the influence of water temperature on the swimming performance of the species.

\section{Materials and Methods}

Individuals of piau-três-pintas ( $L$. reinhardti) were captured during 2005, in the São Francisco River near Três Marias Dam, Minas Gerais State, Brazil. In the laboratory, the fish remained for at least $24 \mathrm{~h}$ in the maintenance system before tests. Two types of swimming performance tests were carried out: variable (increasing) and fixed velocities. The first gives critical speed whereas the second gives prolonged and sustained speeds.

To determine critical speed, 40 tests were performed between February and April of 2005, among which 25 were considered for statistical analysis. Tests were discarded when fish either refused to swim or fatigued immediately after tests started. For these tests, the fish sizes were selected to provide different size classes (Fig.1).

To measure prolonged and sustained speeds, we conducted 30 tests, between October and December of 2005, among which 27 were considered for statistical analysis. Considering the purpose of the study, we selected individuals with total length over $16 \mathrm{~cm}$ (Fig. 2), because this is the size of first maturation (according to Rizzo et al. (1996); 12.9 and 14.0 $\mathrm{cm}$ standard length for males and females, respectively) estimated for the Três Marias region.

Each individual was tested once and after the test it was measured, weighed and the condition factor calculated according the equation 1. After seven days in the laboratory, the fish that had already been tested were returned to the river where they were captured.

$\ln \mathrm{k}=\ln ($ Weigth $)-3 \ln$ (Total length)

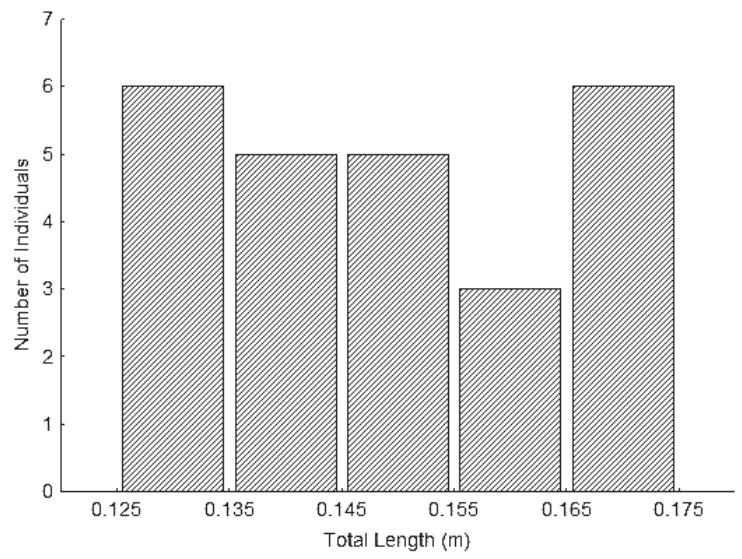

Fig. 1. Number of tested fish per total length classes used to determine critical speed. 


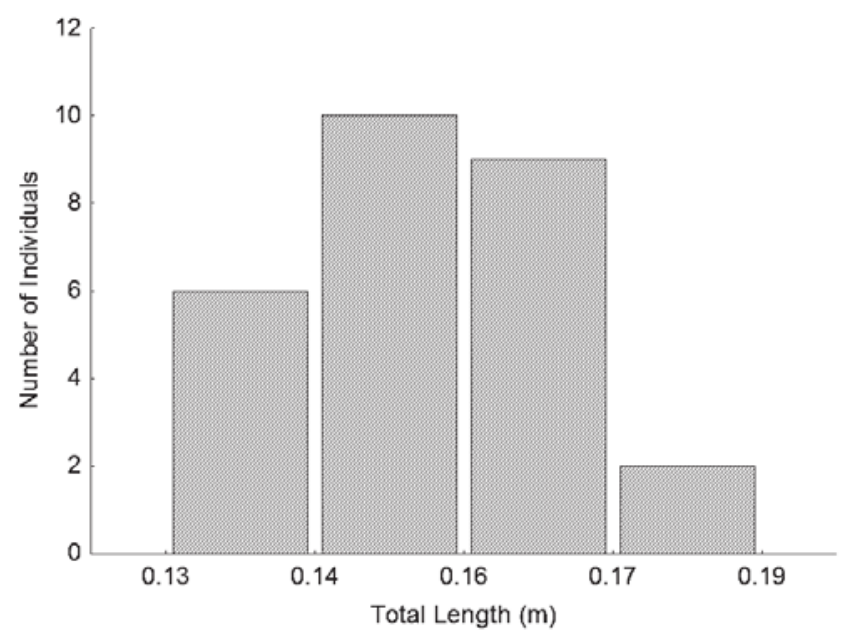

Fig. 2. Number of tested fish per total length classes used to determine prolonged speed.

The experimental apparatus used to measure swimming capacity of the piau-três-pintas was constructed based on the respirometer developed by Brett (1964). It is a hydrodynamic tube with $150 \mathrm{~mm}$ nominal diameter. Its central part is a chamber made of plexiglas which allows visualization of the fish. The flow is driven by two centrifugal pumps with water taken from a reservoir (Santos et al., in press).

The increasing velocity test was based on the experimental procedure of Brett (1964) and the values of critical speed were calculated according to the following expression:

$$
\text { Vcrit }=\mathrm{V}_{\max }+\frac{\mathrm{t}_{\max }}{\Delta \mathrm{t}} \times \Delta \mathrm{V}
$$

where $\mathrm{V}_{\max }$ is the maximum speed, $\mathrm{t}_{\max }$ the time during which the fish swam in the last time interval, $\Delta \mathrm{t}$ the time interval and $\Delta \mathrm{V}$ the speed increment .

Tests started with the acclimation of fish to the water temperature of the respirometer and its introduction to the central chamber. Pumps were turned on and, after a period of $10 \mathrm{~min}$, the water speed was increased in steps of $5 \mathrm{~cm} / \mathrm{s}(\Delta \mathrm{V})$, each lasting $5 \mathrm{~min}(\Delta \mathrm{t})$. These increments were based on the possibilities of speed control of the apparatus and the total time of the test. After successive speed increases, the fish would no longer resist the flow, due to fatigue, which was considered as the moment when the fish could no longer swim in the test chamber, after several burst attempts. We measured the time which the fish swam at such speed $\left(\mathrm{V}_{\max }\right)$ until its fatigue.

Fixed velocity tests were based on the method used by Brett (1967) and Jones et al. (1974). Chosen for these tests were percentage values of the estimated critical speed $(1.32 \mathrm{~m} /$ s) for an individual with a total length of $16 \mathrm{~cm}$ (Table 1). For this analysis, the speed in meters per second (m/s) was transformed into length per second (length/s), dividing the velocity established in the apparatus by the total length of the fish.

Every parameter measured inside the hydrodynamic tube required corrections, because its walls cause effects on measurements (Webb, 1975). The solid blocking effect that oc-
Table 1. Used values of prolonged speed.

\begin{tabular}{cc}
\hline $\begin{array}{c}\text { Prolonged Speed in percentage } \\
\text { values of Critical Speed }\end{array}$ & Prolonged Speed $(\mathrm{m} / \mathrm{s})$ \\
\hline 72 & 0.95 \\
80 & 1.05 \\
87 & 1.15 \\
94 & 1.25 \\
102 & 1.35 \\
110 & 1.45 \\
117 & 1.55 \\
125 & 1.65 \\
\hline
\end{tabular}

curs due to the obstruction of the flow by the body of the fish in the chamber was corrected for each test (performed in increasing and fixed velocity) according to the equation proposed by Rae \& Pope (1966):

$$
\begin{aligned}
& \mathrm{V}_{\text {corrected }}=\frac{\mathrm{V}_{\text {measured }} \mathrm{K}_{3} \tau_{1}(\text { fish volume })}{\mathrm{C}^{3 / 2}} \\
& \text { Volume }=0.45 \mathrm{e}^{2} \mathrm{~L}
\end{aligned}
$$

where $\mathrm{K}_{3}$ is the shape factor, $\mathrm{t}_{1}$ the factor considering the layout of the cross-section of the chamber (circular sections $\left.\tau_{1}=0.8\right), C$ the cross-sectional area of the chamber, $e$ the maximum width of the fish (the mean between the maximum width and height) and $L$ the length of the fish.

During all tests, water quality inside the apparatus was continuously monitored ( $\mathrm{pH}$, dissolved oxygen and temperature). The relationships between the critical speed and the length (total and standard), weight and condition factor of the fish and water temperature were tested by linear regressions (variables were natural logarithm transformed). The same procedure was adopted for the relationships between prolonged speed and fatigue time as well as fatigue time and percentage of fatigued fish. Statistical significance was implied when $\mathrm{P}<0.05$. The coefficient of determination was used as a criterion to identify the best model. All analyses were performed using the software Statistica ${ }^{\text {TM }}$.

From the relationships between critical speed, fish size and temperature, speed versus fish size curves for lower temperatures were estimated for $L$. reinhardti. The swimming performance of $L$. reinhardti was compared with the data from the temperate zone presented in the literature. For the species studied, we used the data obtained in the laboratory as well as the estimation for 20,15 and $10^{\circ} \mathrm{C}$.

\section{Results}

In all tests performed, the water quality in the experimental apparatus was considered good for fish, with dissolved oxygen concentrations greater than $5 \mathrm{mg} / \mathrm{l}$, temperatures ranging from 24 to $28^{\circ} \mathrm{C}$ and $\mathrm{pH}$ ranging from 6 to 9 .

\section{Increasing velocity tests}

The results of the increasing velocity tests showed significant relationships between the critical speed, total and standard lengths and body weight. However, the total length 
was the variable with the greatest significance (greater value of the coefficient of determination) (Fig. 3). On the other hand, there was no relationship between condition factor and critical speed.

Temperature, when associated with the total length, despite its slight variation during the tests, also influenced the critical speed shown by the species $\left(\mathrm{R}^{2}=0.48\right.$ and $\mathrm{P}$-value $<$ 0.001).

When compared to other species whose critical speed data are available, we observed that the piau shows superior speeds, for an equal total length (Fig. 4). Table 2 shows the experimental conditions in which such curves were obtained and their statistical parameters.

When we estimated the critical speeds that would be developed by this species for lower temperatures (20, 15 and $10^{\circ} \mathrm{C}$ ), we obtained speed curves close to those of the salmo-

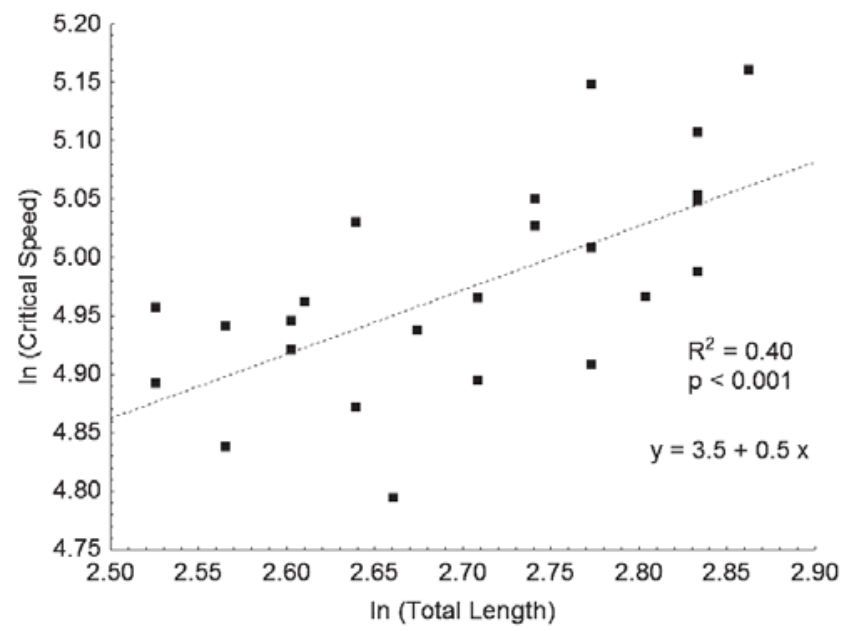

Fig. 3. Scatterplot of the relationship between $\ln$ of the critical speed $(\mathrm{cm} / \mathrm{s})$ and the $1 n$ of the total length $(\mathrm{cm})$. Dotted line represents the fit of the model.

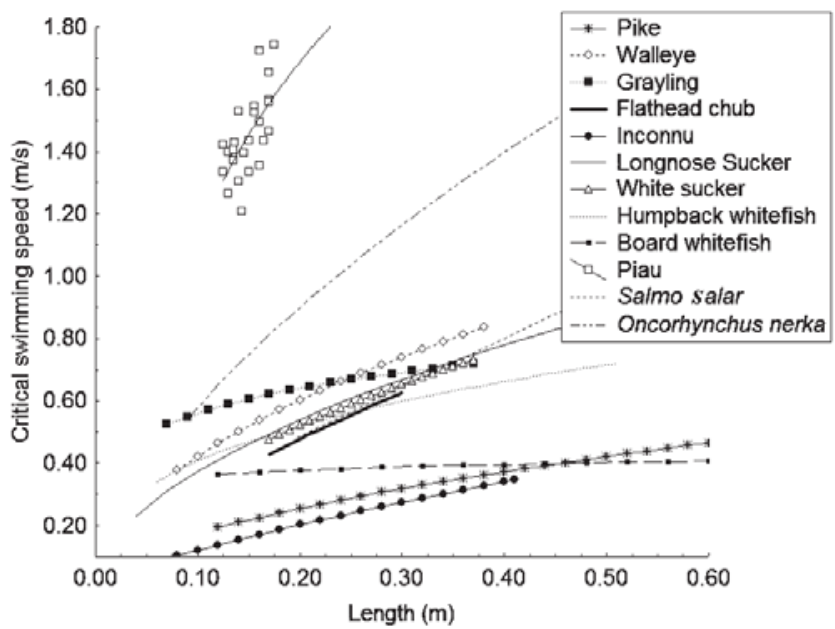

Fig. 4. Curves representing the relationship between critical swimming speed $(\mathrm{m} / \mathrm{s})$ and length $(\mathrm{m})$ for the piau (continuous line in the squares on the top left of the figure) and some species from the temperate zone. Full names of some species are given in Table 2). nids Salmo salar and Oncorhynchus nerka, for the same temperature range (Fig. 5).

\section{Fixed Velocity Tests}

Fatigue times per prolonged speed class (Fig.6) were estimated as well as prolonged speed per fatigue time class (Fig.7). It was possible to establish by these relationships the point of change from sustained to prolonged swimming. If, according to Brett (1967), a speed can be held by the fish for more than $200 \mathrm{~min}$, it is accepted as continuous (sustained or aerobic endurance) swimming. This change was estimated to occur approximately at a speed of seven lengths per second for the piau (Fig. 6). For an individual of the first maturation size $(16 \mathrm{~cm})$, this speed would be approximately $1.12 \mathrm{~m} / \mathrm{s}$.

The percentage of fatigued fish for a given swimming time was also obtained for the speeds of 6.8, 9.2 and 10.7 lengths

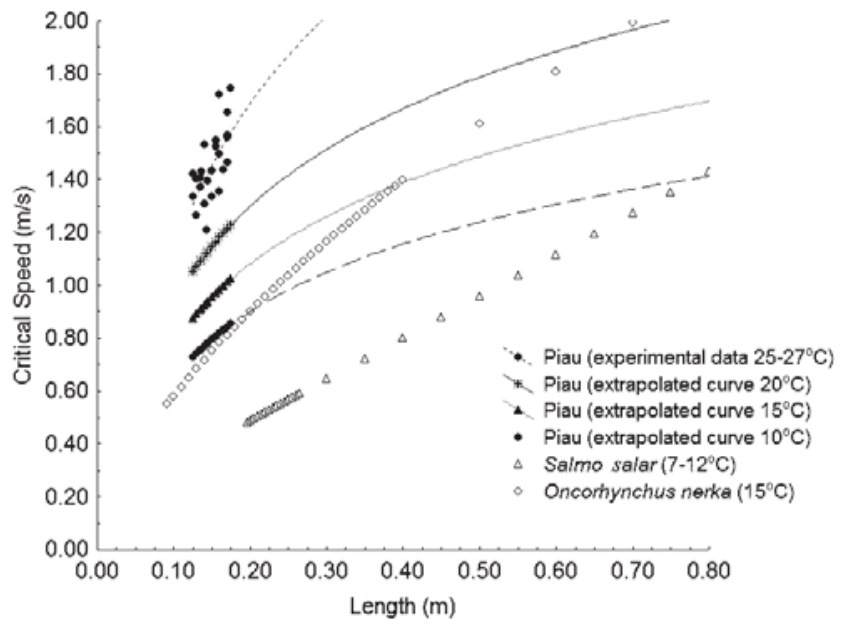

Fig. 5. Curves representing the relationship between critical speed $(\mathrm{m} / \mathrm{s})$ and length $(\mathrm{m})$ for the piau at different temperatures, compared to two salmonids (Salmo salar and Oncorhynchus nerka).

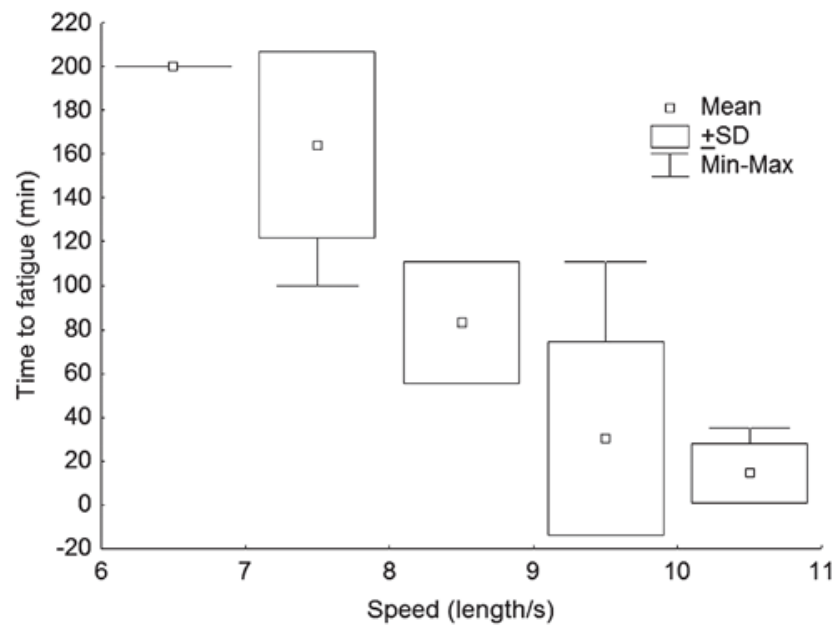

Fig. 6. Mean ( \pm standard deviation $-\mathrm{SD}$; minimum - Min; and Maximum - Max) values of time to fatigue (min) per speed class (lengths/s) for piau Leporinus reinhardti. 
Table 2. Experimental and statistical aspects of known critical speed curves ( ${ }^{*}$ p-value for correlation coefficient).

\begin{tabular}{|c|c|c|c|c|c|c|c|c|}
\hline Species & $\mathrm{n}$ & Equation & $\left(\mathrm{r}^{2}\right)$ & p-value & Temp ${ }^{\circ} \mathrm{C}$ & $\Delta \mathrm{V}(\mathrm{cm} / \mathrm{s})$ & $\Delta \mathrm{t}(\mathrm{min})$ & Author \\
\hline Esox lucius (Pike) & 192 & $V=4.9 L^{0.55}$ & 0.194 & $0.001^{*}$ & $12-13$ & 10 & 10 & Jones et al. (1974) \\
\hline Stizostedion vitreum (Walleye) & 54 & $V=13.07 L^{0.51}$ & 0.000 & $0.1 *$ & $12-13$ & 10 & 10 & Jones et al. (1974) \\
\hline Thymallus arcticus (Grayling) & 94 & $V=36.23 L^{0.19}$ & 0.049 & $0.02 *$ & $12-13$ & 10 & 10 & Jones et al. (1974) \\
\hline Platygobio gracilis (Flathead chub) & 28 & $V=6.42 L^{0.67}$ & 0.095 & $0.1 *$ & $12-13$ & 10 & 10 & Jones et al. (1974) \\
\hline Stenodus leucichthys (Inconnu) & 22 & $V=2.14 L^{0.75}$ & 0.031 & $0.1^{*}$ & $12-13$ & 10 & 10 & Jones et al. (1974) \\
\hline Catostomus catostomus (Longnose sucker) & 169 & $V=11.03 L^{0.53}$ & 0.619 & $0.0001 *$ & $12-13$ & 10 & 10 & Jones et al. (1974) \\
\hline Catostomus commersoni (White sucker) & 20 & $V=10.03 L^{0.55}$ & 0.251 & $0.02 *$ & $12-13$ & 10 & 10 & Jones et al. (1974) \\
\hline Coregonus clupeaformis (Humpback whitefish) & 159 & $V=18.2 L^{0.35}$ & 0.130 & $0.0001^{*}$ & $12-13$ & 10 & 10 & Jones et al. (1974) \\
\hline Coregonus nasus (Board whitefish) & 33 & $V=9.7 L^{0.45}$ & 0.250 & $0.003 *$ & $12-13$ & 10 & 10 & Jones et al. (1974) \\
\hline Salmo salar (Atlantic salmon) & 55 & $V=17.3+1.57 L$ & 0.0361 & $?$ & $7-12$ & 5 & 5 & McCleave \& Stred (1975) \\
\hline Oncorhynchus nerka (Sockeye salmon) & 6 & $V=13.47 L^{0.6345}$ & ? & $<0.05$ & 15 & 10 & 60 & Brett \& Glass (1973) \\
\hline Leporinus reinhardti (Piau três-pintas) & 25 & $V=3.31 L^{0.5}$ & 0.40 & $<0.001$ & $12.5-17.5$ & 5 & 5 & Present study \\
\hline
\end{tabular}

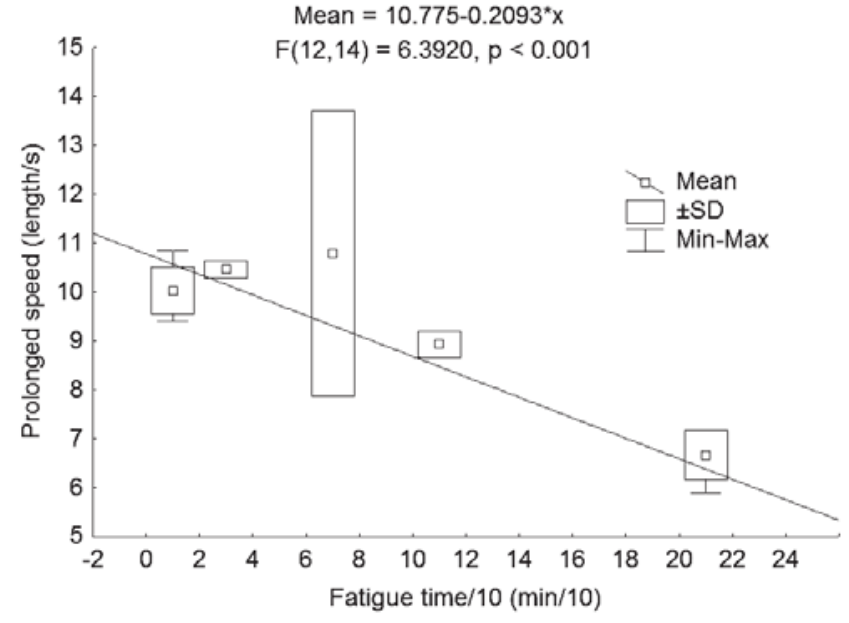

Fig. 7. Mean ( \pm standard deviation $-\mathrm{SD}$; minimum - Min; and Maximum - Max) values of prolonged speed (length/s) per fatigue time $(\mathrm{min} / 10)$ for the piau Leporinus reinhardti .

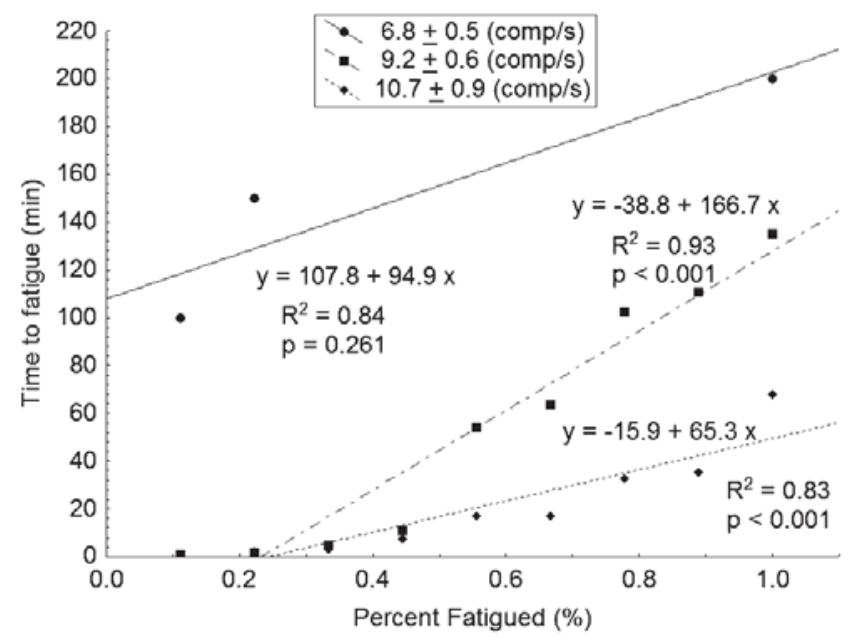

Fig. 8. Scatterplot of the relationship between time to fatigue (min) and percent fatigued for piaus of three different speed classes (lines represent fit of the models for each size class). per second. For each of these speeds, the times in which $50 \%$ of the tested individuals fatigued were 155,45 and $17 \mathrm{~min}$, respectively (Fig. 8).

\section{Discussion}

The results obtained in the present paper for the piau três-pintas, Leporinus reinhardti, were the first speeds measured in the laboratory for a species of such genus. So far, only some qualitative observations were known concerning Leporinus friderici, when passing by a rapid with flow speed of $13 \mathrm{~m} / \mathrm{s}$ (Godoy, 1985). Despite the limitations of this finding, since there is no knowledge about the size of the fish and the type of speed performed to overcome such flow speed barrier, the value greatly differed from the values described in this study. According to Brett (1967), burst swimming can be held for $20 \mathrm{~s}$. For piau, speed higher than 10.76 length/s was burst velocity, obtained from the prolonged speed curve to fatigued time of $20 \mathrm{~s}$. The values of burst speed estimated from the maximum sizes of L. reinhardti $(23 \mathrm{~cm}$ : Alves \& Pompeu, 2004) and L. friderici (40 cm: Reis et al., 2003), correspond to $2.47 \mathrm{~m} / \mathrm{s}$ and $4.30 \mathrm{~m} / \mathrm{s}$, respectively.

However, the speeds developed by fish inside the respirometer, such as Brett's, are lower than those determined in natural conditions of migration. This difference is due to the behavioral refusal of confined fish to swim to complete physiological exhaustion, and/or differences in the energetic costs associated with confined and unconfined swimming (Peake, 2004). Besides, at the end of the step tests, fishes swim rapidly and probably anaerobically, whereas during endurance tests, fishes swim relatively slowly and most of them probably swim aerobically (Kolok, 1992). Consequently, step tests tend to underestimate the endurance of fishes by pre-exhausting them at anaerobic levels. Another explanation for the observed difference lies in the fact that the point where Godoy (1985) determined the flow speed $(13.8 \mathrm{~m} / \mathrm{s})$, probably does not correspond to the passing region of $L$. friderici. Facing speed barriers, fish negotiate their passage in a region of lower flow speeds, or a region where speeds are within their swimming capability.

The same behavior leads, several times, to a separation of 
species in the transversal speed profile of a water course. In Brazilian rivers, this separation is clear when we compare bottom dwelling species, such as the mandi-amarelo (Pimelodus maculatus), to those that prefer the water-column such as Leporinus reinhardti. The difference between the swimming capacities of these two species is significant. In the case of the mandi-amarelo, an individual with $15 \mathrm{~cm}$ total length swims at $1.10 \mathrm{~m} / \mathrm{s}$ in critical prolonged mode (Santos et al., in press), whereas a piau with the same length swims at $1.28 \mathrm{~m} / \mathrm{s}$. However, despite the fact that the swimming speeds of bottom fishes are typically slower when compared to fish that swim in the middle of the water column, the migratory progress of both groups relative to the river banks is roughly equivalent (Pavlov, 1989), due to transversal speed profile differences.

Compared to other critical speed studies, the curves obtained for the piau showed higher $\mathrm{R}^{2}$ values, despite the low number of individuals tested. The strong relationship between critical speed and total length reflects the importance of the caudal fin, an important propulsion element in fish which has a subcarangiform type of locomotion pattern (Webb, 1994), such as in the case of the Anostomidae.

In the tests, the piau showed higher critical speeds when compared to several species from the temperate zone. The measurement of critical speed values depends on an array of factors, such as the experimental procedures and the water temperatures during the tests which mainly influence the process to attain this velocity. According to Hammer (1995), this dependence may make the comparisons between critical speeds among species susceptible to errors. Considering the procedures of our experiments, speed increments $(\Delta \mathrm{V})$ and time increments $(\Delta \mathrm{t})$ significantly influenced the values of the critical speeds (Farlinger \& Beamish, 1977). However, the differences between the experimental procedures could not explain the variations observed in the values of critical speed. According to Farlinger \& Beamish (1977), if we adopted a $\Delta t$ of $60 \mathrm{~min}$ and a $\Delta \mathrm{V}$ of $10 \mathrm{~cm} / \mathrm{s}$, the outcome of the critical speed would be only $6 \%$ lower. If $\Delta \mathrm{t}$ was $10 \mathrm{~min}$ and $\Delta \mathrm{V}$ was $10 \mathrm{~cm} / \mathrm{s}$, the critical speed would be greater than that obtained with $\Delta \mathrm{t}$ of $5 \mathrm{~min}$ and $\Delta \mathrm{V}$ of $5 \mathrm{~m} / \mathrm{s}$. Therefore, the experimental procedures do not explain the differences observed between the piau and the species from the temperate zone.

Although there was a small variation in temperature, it explained $30 \%$ of the critical speed measured for the piau. Temperature is considered the main environmental factor related to the swimming performance of fish (Videler, 1993). Generally, within the thermal range of tolerance for a given species, prolonged speeds increase with temperature to a maximum (optimum temperature) and thereafter decline (Beamish, 1978).

The effects of temperature on fish swimming can be divided into physical and physiological effects. The first is due to changes in water properties, such as specific mass and viscosity, capable of altering the swimming kinematics through drag forces (White, 2002). The physiological effects are generally attributed to differences in molecular kinetics and the rates of the biochemical reactions that convert chemical energy into propulsive thrust (Beamish, 1978). The relationship found between water temperature and speed of the piau is in accordance to the variations encountered for tests performed in species from the temperate region. In general, a decrease of approximately $10^{\circ} \mathrm{C}$ in water temperature, promotes a decrease ranging from 24 to $37 \%$ in swimming capacity (Gibson \& Fry, 1954; Brett, 1964; Otto \& Rice, 1974; Glova \& McInerney, 1977).

The physical effects will be stronger for fish swimming in a viscous hydrodynamic regime and will be negligible in an inertial regime (Fuiman \& Batty, 1997). When the dimensionless Reynolds number ( $\mathrm{Re})$ is more than 1000 , the viscous force can be ignored. Routine swimming speeds of most adult fishes, over a large range of sizes, are equivalent to the inertia hydrodynamic regime, with $\mathrm{Re}>10^{4}$ ( Wu, 1977). Therefore, the physiological effects were probably the main cause for the significant differences between tests found for the speed of piau, which swims in higher temperatures than species from the temperate zone. Our results indicate too, that temperature changes, resulting from reservoir formation, may modify the piau speed during spawning migration.

Despite that the critical speed is a powerful tool to compare swimming capacity among species (Hammer, 1995), its use is limited, since this speed is lower than the speed developed in open channels (Peake, 2004), and it also has little biological significance. Endurance tests provide a more accurate measure of the swimming ability of a fish for a certain time span, for a given speed (Kolok, 1992). Thus, for the dimensioning of fish passage mechanisms, it is common to use prolonged speeds (Katopodis, 2005), which allows the acquisition of specific information on how long (endurance time) or how far (swimming distance) a particular fish can swim against a given water velocity (Katopodis, 1992). From the data obtained for Leporinus reinhardti, it is possible to estimate the mean velocity inside a fish ladder needed for a fish to ascend it, reaching the reservoir in a certain time. For example, the maximum flow speed inside a $100 \mathrm{~m}$ fish ladder should be $1.06 \mathrm{~m} / \mathrm{s}$, since a $16-\mathrm{cm}$ long (total length) individual can swim 7 lengths per second $(1.12 \mathrm{~m} / \mathrm{s}-$ minimum value of prolonged speed) and the time limit to ascend the ladder would be $30 \mathrm{~min}$.

Due to the lack of basic information on the biology of neotropical migratory species, important biological factors were not considered in fishway projects in South America. However, the high swimming capacity of the piau Leporinus reinhardti explained the success of genera in ascending fishways constructed in Brazil. Species of Leporinus are often abundant in fishways, sometimes with higher abundance than the large-sized migratory species, such as the dourado (Salminus spp.) and the curimatã (Prochilodus spp.) (Fernandez et al., 2004; Vono et al., 2004; Bizzoto, 2006; Pompeu, 2006). However, it is possible that the swimming capacity of this genus is greater than that of other migratory Characiformes. At Santa Clara Dam (in Mucuri River, Minas Gerais State), 16.1\% of the individuals of Leporinus 
conirostris downstream from the dam passed through the fishway, against only $5.7 \%$ of Prochilodus vimboides and $3.1 \%$ of other species (Pompeu, 2005). These findings indicate the great capacity of the piau in overcoming the obstacles represented by a fishway.

It is also important to consider that the maximum flow speeds $(2 \mathrm{~m} / \mathrm{s})$ established for South American fishways were based, mainly, on the swimming capacity of salmonids, which, despite having an inferior speed for a given size, can be faster due to their larger size as adults. The burst speed $(1.72 \mathrm{~m} / \mathrm{s})$, maintained for $20 \mathrm{~s}$ by a piau of $16 \mathrm{~cm}$ is smaller than the guideline velocity used in fishway designs. Therefore, piau individuals will not be able to ascend passages using the $2 \mathrm{~m} /$ $\mathrm{s}$ criterion, in spite of its great swimming performance.

The adoption of efficient directives in fishway projects, to allow the passage of neotropical ichthyofauna, will depend on a more detailed analysis of the swimming capacity of different species. Similar studies for Prochilodus and Salminus species are necessary because they represent a great part of the biomass in rivers and are important for the fisheries in South American rivers (Welcomme, 1985).

However, the data obtained for Leporinus reinhardti represent an important contribution to the knowledge about the species, and they were added to the current "Ichthyomechanical Data Base." This database provides guidance and criteria for designing several structures, such as fishways, fish screens and other systems and provides estimates of the range of swimming performance for several fish species and sizes (Katopodis, 2005).

\section{Acknowledgments}

We are grateful to CEMIG for the logistics and financial support. Special thanks go to César Augusto Muniz Toledo and Lívia Duarte Ventura Melo, students who helped us in the experimental tests, and to Geraldo Garcia, Vicente Pimenta and Paulo Roberto, workers who helped us in the construction of experimental apparatus.

\section{Literature Cited}

Agostinho, A. A. 1994. Pesquisas, monitoramento e manejo da fauna aquática em empreendimentos hidrelétricos. Pp. 38-59. In: COMASE. Seminário sobre fauna aquática e o setor elétrico brasileiro: fundamentos, reuniões temáticas preparatórias: caderno1- Fundamentos. Rio de Janeiro, ELETROBRÁS, 61p..

Alves, C. B. M. \& P. S. Pompeu. 2005. Historical changes in the Rio das Velhas fish fauna- Brazil. American Fisheries Society Symposium, 45: 587-602.

Beach, M. H. 1984. Fish pass design-criteria for the design and approval of fish passes and other structures to facilitate the passage of migratory. Lowestoff, Ministry of agriculture, fisheries and food, 46p.

Beamish, F. W. H. 1978.Swimming capacity. Pp.101-187. In. Hoar, W. S. \& D. J. Randall (Ed.). Fish Physiology. New York, Academic Press, 576p.
Bittencourt, M. M. \& C. Cox-Fernandes. 1990. Peixes migradores sustentam pesca comercial. Ciências Hoje, 11(64): 20-24.

Bizotto, P. M. 2006. Trânsito de peixes na escada da UHE-Igarapava, Rio Grande, Alto Paraná. Unpublished Dissertation, Pontifícia Universidade Católica de Minas Gerais, Belo Horizonte, 52p.

Brett, J. R. \& N. R. Glass. 1973. Metabolic rates and critical swimming speeds of sockeye salmon (Oncorhynchus nerka) in relation to size and temperature. Journal of the Fisheries Research Board of Canada, 30: 379-387.

Brett, J. R. 1964. The respiratory metabolism and swimming performance of young Sockeye Salmon. Journal of the Fisheries Research Board of Canada, 21(5): 1183-1226.

Brett, J. R. 1967. Swimming performance of Sockeye Salmon (Oncorhynchus nerka) in relation to fatigue time and temperature. Journal of the Fisheries Research Board of Canada, 21(8): 1731-1741.

Clay, C. H. 1995. Design of fishways and other fish facilities. Boca Raton, CRC Press, 248p.

Farlinger, S. \& F. W. H. Beamish. 1977. Effects of time and velocity increments on the critical swimming speed of Largemouth Bass (Micropterus salmoides). Transaction of the American Fisheries Society, 106(5): 436-439.

Fernandez, D. R., A. A. Agostinho \& L. M. Bini. 2004. Selection of an experimental fish ladder located at the dam of the Itaipu Binacional, Paraná River, Brazil. Brazilian Archives of Biology and Technology, 47(4): 579-586.

Fuiman, L. A. \& R. S. Batty. 1997. What a drag it is getting cold: partitioning the physical and physiological effects of temperature on fish swimming. The Journal of Experimental Biology, 200: 1745-1755.

Gibson, E. S. \& F. E. Fry. 1954. The performance of the lake trout, Salvelinus namaycush, at various levels of temperature and oxygen pressure. Canadian Journal of Zoology, 32: 252-260.

Glova, G. J. \& J. E. McInerney. 1977. Critical swimming speeds of Coho Salmon (Oncorhynchus kisutch) fry to smolt stages in relation to salinity und temperature. Journal of the Fisheries Research Board of Canada, 34: 151-154.

Godinho, A. L. 1993. E os peixes de Minas em 2010? Ciência Hoje, 16(91): 44-49.

Godinho, H. P. \& A. L. Godinho. 1994. Ecology and conservation of fish in southeastern Brazilian river basins submitted to hydroelectric impoundments. Acta Limnologica Brasiliensia, 5:187-197.

Godoy, M. P. 1967. Dez anos de observações sobre periodicidade migratória de peixes do Rio Mogi Guassu. Revista Brasileira de Biologia, 27: 1-12.

Godoy, M. P. 1985. Aquicultura. Atividade multidisciplinar. Escadas e outras facilidades para passagens de peixes. Estações de piscicultura. Florianópolis, Eletrosul, 77p.

Goulding, M. 1979. Ecologia da pesca do rio Madeira. Manaus, CNPq/INPA. 172p.

Hammer, C. 1995. Fatigue and exercise tests with fish. Comparative Biochemistry and Physiology, 112(1): 1-20.

Jones, D. R., J. W. Kiceniuk \& O. S. Bamford. 1974. Evaluation of the swimming performance of several fish species from the Mackenzie River. Journal of the Fisheries Research Board of Canada, 31(10): 1641-1647.

Katopodis, C. 1992. Introduction to Fishway Design. Winnipeg, Freshwater Institute, 67p.

Katopodis, C. 2005. Developing a toolkit for fish passage, ecological flow management and fish habitat works. Journal of Hydraulic Research, 43(5): 451-467. 
Kolok, A. S. 1992. The swimming performance of individual largemouth bass (Micropterus salmoides) are repeatable. Journal of Experimental Biology, 170: 265-270.

McCleave, J. D. \& K. Stred. 1975. Effect of dummy telemetry transmitters on stamina of Atlantic salmon (Salmo salar) smolts. Journal of the Fisheries Research Board of Canada, 32(4): 559563.

Northcote, T. G. 1978. Migratory strategies in production in freshwater fishes. Pp. 326-359. In: Gerking, S. D. (Ed.). Ecology of freshwater fish production. Oxford, Blakwell Scientific Publications, 520p.

Otto, R. G. \& J. O. Rice. 1974. Swimming speeds of Yellow Perch (Perca flavescens) following an abrupt change in environmental temperature. Journal of the Fisheries Research Board of Canada, 31: 1731-1734.

Pavlov, D. S. 1989. Structures assisting the migrations of nonsalmonid fish: USSR. FAO, 97p.

Peake, S. 2004. An evaluation of the use of critical swimming speed for determination of culvert water velocity criteria for smallmouth bass. Transaction of the American Fisheries Society, 133: 1472-1479.

Petrere Jr., M. 1985. Migraciones de peces de agua dulce en America Latina: algunos comentarios. COPESCAL Documento Ocasional, $1: 17 \mathrm{p}$.

Pompeu, P. S. 2005. Estudo da regra operativa e avaliação de um mecanismo de transposição de peixes do tipo elevador com caminhão-tanque. Unpublished Doctor Dissertation. Federal University of Minas Gerais, Belo Horizonte. 190p.

Pompeu, P. S. \& C. B. Martinez. 2006. Variações temporais na passagem de peixes pelo elevador da usina Hidrelétrica de Santa Clara, rio Mucuri, leste brasileiro. Revista Brasileira de Zoologia, 23(2): 340-349.

Quirós, R. 1989. Structures assisting the migrations of non-salmonid fish: Latin America. Rome, FAO, 41p.

Rae, W. H. \& A. Pope. 1984. Low-speed wind tunnel testing. New York, John Wiley \& Sons, 534p.
Reis, R. E., S. O. Kullander \& C. J. Ferraris Jr. (Eds.). 2003. Check list $\mathrm{f}$ the freshwater fishes of South and Central America. Porto Alegre, EDIPUCRS, 729p.

Rizzo, E., Y. Sato, R. M. A. Ferreira, H. Chiarini-Garcia, \& N. Bazzoli. 1996. Reproduction of Leporinus reinhardti (Pisces: Anostomidae) from the Três Marias Reservoir, São Francisco River, Minas Gerais, Brazil. Ciência e Cultura 48 (3): 189-192.

Sale, M. J. 1985. Aquatic ecosystem response to flow modification: an overview of the issues. Pp. 25-31. In: Olson, F. W. (Ed.). Proceedings of the symposium on small hydropower and fisheries. Bethesda, American Fisheries Society, 497p.

Santos, H. A., P. S. Pompeu, G. C. Vicentini \& C. B. Martinez (in press). Swimming performance of the freshwater neotropical fish: Pimelodus maculatus. Brazilian Journal of Biology, 2008.

Sato, Y., E. L. Cardoso \& J. C. C. Amorim. 1987. Peixes das lagoas marginais do São Francisco a montante da represa de Três Marias (Minas Gerais). Brasília, CODEVASF, 42 p.

Videler, J. J. 1993. Fish swimming. London, Chapman \& Hall, 260p. Vono, V., P. M. Bizzotto, H. P. Godinho, A. L. Godinho, \& B. Kynard. 2004. Fish passage at the Igarapava Fish Ladder, River Grande, Brazil. Pp. 1-5. In: Annals of the International Congress on the Biology of Fish Tropical Hotel Resort. Manaus, American Fisheries Society.

Webb, P. W. 1975. Hydrodynamics and energetics of fish propulsion. Bulletin of the fisheries research board of Canada, 190: 1-158.

Webb, P. W. 1994.The biology of fish swimming. Pp.45-62. In. Mechanics and physiology of animal swimming. Cambridge University Press, Cambridge, $250 \mathrm{p}$.

Welcomme, R. L. 1985. River fisheries. FAO Fisheries, 330p.

White, F. M. 2002. Mecânica dos Fluidos. Rio de Janeiro, McGraw Hill Companies, 570p.

$\mathrm{Wu}, \mathrm{T}$. Y. 1977. Introduction to the scaling of aquatic animal locomotion. Pp. 203-232. In: Pedley, T. J. (Ed.). Scale Effects in Animal Locomotion. New York, Academic Press, 545p.

Received January 2007 Accepted June 2007 